\title{
Comparison between different dilution rates on canine semen freezing using Tris-buffer with the addition of egg-yolk and glycerol
}

\author{
[Comparação entre diferentes diluições na congelação do sêmen canino utilizando o tampão \\ tris acrescido de gema de ovo e glicerol]
}

\author{
A.R. Silva, R.C.S. Cardoso, L.D.M. Silva \\ ${ }^{1}$ Programa de Pós-Graduação em Ciências Veterinária \\ Universidade Estadual do Ceará \\ Avenida Paranjana, 1700 - Itaperi \\ 60740-000 - Fortaleza, CE
}

\begin{abstract}
Standardized sperm concentration and volume:volume extension were compared as dilution rates for canine semen freezing. Six proven stud dogs were submitted to two seminal collections by manual stimulation. Semen was evaluated and extended in tris plus egg-yolk and glycerol according to two different dilution rates. The first one was based on a standardized sperm concentration of $200 \times 10^{6}$ spermatozoa $/ \mathrm{ml}$ and the second was a volume:volume extension at a proportion of one part semen to one part extender. Semen was frozen, stored in liquid nitrogen and thawed after one week. Sperm motility and vigor were appraised after each stage of the process and at 15 and 30min post-thawing. Sperm morphology was analyzed after collection and thawing. No differences were observed between treatments after thawing regarding sperm motility and vigor, normal sperm morphology rate or longevity. Both dilution rates can be efficiently used for canine semen freezing.
\end{abstract}

Keywords: dog, semen, extender, freezing, dilution

\section{RESUMO}

Compararam-se a concentração espermática padronizada e a expansão volume:volume na diluição do sêmen canino para congelação. O sêmen de seis cães, submetidos a duas coletas por estimulação manual, foi avaliado e diluído em tris acrescido de gema de ovo e glicerol, de acordo com duas diferentes diluições. A primeira baseou-se na concentração espermática padronizada de $200 \times 10^{6}$ espermatozóides $/ \mathrm{ml}$, e a segunda mediante diluição volume:volume, na proporção de uma parte de sêmen para uma de diluidor. O sêmen foi congelado, armazenado em nitrogênio líquido e descongelado após uma semana. A motilidade e o vigor espermáticos foram avaliados a cada etapa do processo e aos 15 e 30min após descongelação. A morfologia espermática foi avaliada após coleta e descongelação. Nenhuma diferença foi observada entre os tratamentos após a descongelação quanto à motilidade, vigor, porcentagem de espermatozóides morfologicamente normais e longevidade. Ambas as taxas de diluição podem ser eficientemente utilizadas na congelação do sêmen canino.

Palavras-chave: cão, sêmen, diluidor, congelação, diluição

Recebido para publicação em 17 de março de 2004

Recebido para publicação, após modificações, em 19 de outubro de 2004

E-mail: legio2000@yahoo.com

Apoio: CAPES, CNPq 


\section{INTRODUCTION}

Nowadays, some chilling methods have been yielding expressive results in conserving canine semen for several days (Iguer-Ouada, 2001), allowing semen exchange between countries. However, cryopreservation continues to be an important tool for the conservation of genetic material from valuable stud dogs for an indefinite time. Moreover, due to philogenetic similarities between the domestic and nondomestic canids, the former are used as an experimental model for the latter, mainly because of the lack of availability of nondomestic canids for use in experiments (Goodrowe et al., 1998; Silva et al., 2004). For this reason, scientific research has been carried out in an attempt to improve different protocols for this procedure by using different cryoprotective agents (Soares et al., 2002; Silva et al., 2003), extenders (Bueno et al., 2001; Cardoso et al., 2003), freezing/thawing processes, and several dilution rates (England, 1993).

In general, investigations on canine semen technology use a dilution rate based on a standardized sperm concentration. The advantage of this method is that it is simpler to calculate the number of spermatozoa per straw, allowing the preparation of semen doses for artificial insemination. Furthermore, standardized concentration allows the researcher to determine the exact proportion between the extender and the sperm cells. Several authors have reported the use of sperm concentrations ranging from 100 (Tsutsui et al., 2000; Bueno et al., 2001), 200 (Sirivaidyapong et al., 2001), 400 and $800 \times 10^{6}$ spermatozoa/ml (Peña and LindeForsberg, 2000) for canine semen freezing.

On the other hand, investigators have been conducting their research based on a volume:volume extension. By this method, there is no need to count spermatozoa using counting chambers or expensive methods such as spectrophotometry or computer assisted semen analysis. The absence of this step on the methodology renders it more practical, reducing the time and the costs involved in canine semen freezing. Thus, some authors have been using dilutions consisting of one part semen to: one part extender (Cardoso et al., 2003; Silva et al., 2003), two parts extender (Silva and Verstegen, 1995), three parts extender (Yildiz et al., 2000) and four parts extender (England and Ponzio, 1996).

According to England (1993), the standardized sperm concentration method neglects the effect of dilution upon sample viability and the variation in extender constituent concentration. Indeed, the studies that use variable dilution rates do not make accurate comparisons between extenders, as final concentrations are often unknown. There is no evidence that the relationship between chemical concentration and sperm concentration is important; thus, if the final concentration of the chemical is relevant, studies should utilize volume:volume dilutions of semen with an extender.

In view of the controversial information concerning the ideal dilution rate for canine semen, the objective of the present study was to compare standardized sperm concentration and volume:volume extension as dilution rates for canine semen freezing using a tris-buffer extender containing egg-yolk and glycerol.

\section{MATERIAL AND METHODS}

Six proven stud dogs from private kennels were selected for this experiment: one Dobermann, one American Staffordshire Terrier, one Rottweiler, one Brazilian Mastiff and two Boxers. The dogs were aged from one to six years. The animals were maintained in individual boxes and fed dry food once daily, with free access to water.

Each dog was submitted to two seminal collections by manual stimulation. Ejaculates were collected into a funnel coupled to a graduated tube and fractions were separated by color modification (Johnston et al., 2001). The sperm-rich fraction was evaluated and later individually frozen. Semen volume, color and viscosity were grossly evaluated. Sperm motility (percentage of mobile spermatozoa) and vigor (sperm motility status), scored on a scale from 0 (without movement) to 5 (fast progressive movement), were evaluated by light microscopy (100x). Sperm morphology was evaluated by microscopic analysis $(1000 \mathrm{x})$ of a slide stained with eosin-nigrosin, counting 200 cells per slide. Morphologic sperm abnormalities were classified according to Johnston et al. (2001). Sperm 
concentration was determined with a Neubauer counting chamber.

Only samples that presented a volume $\geq 0.6 \mathrm{ml}$, concentration $>200 \times 10^{6}$ spermatozoa $/ \mathrm{ml}$, sperm motility $\geq 80 \%$ and vigor $\geq 4$ were used in the experiment. Samples were divided in two aliquots. The first was submitted to dilution according to standard sperm concentration. After determination of sperm concentration in fresh semen, the needed extender volume was calculated by the formula: $\mathrm{V}_{1} \mathrm{C}_{1}=\mathrm{V}_{2} \mathrm{C}_{2}$, where $\mathrm{V}_{1}$ is the initial volume, $\mathrm{C}_{1}$ the initial concentration in fresh semen, $V_{2}$ the final volume after extension, and $\mathrm{C}_{2}$, the final sperm concentration, which was standardized as $200 \times 10^{6}$ spermatozoa $/ \mathrm{ml}$. The second aliquot was submitted to volume:volume extension based on a proportion of one part semen to one part extender $(1: 1)$

An extender consisting of $3.028 \mathrm{~g}$ tris-hydroxymethyl-aminomethane, $1.78 \mathrm{~g}$ monohydrated citric acid and $1.25 \mathrm{~g}$ D-fructose, dissolved in $100 \mathrm{ml}$ distilled water (Silva et al., 2002) was used. The osmosis of this solution was $305 \mathrm{mOsm} / 1$ and the $\mathrm{pH}$ 6.6. Twenty percent of this solution was then replaced with egg-yolk and the extender was divided into two equal portions. The first portion did not contain the cryoprotector and was added to semen at $27^{\circ} \mathrm{C}$. The second contained $12 \%$ glycerol and was added to semen when both reached $4^{\circ} \mathrm{C}$. After addition, the final glycerol concentration was $6 \%$.

Semen was frozen by adding the first portion of the extender to the semen at $27^{\circ} \mathrm{C}$ immediately after the initial analysis. A cooling period was then allowed when the semen was maintained in a thermal box at $15^{\circ} \mathrm{C}$ for $40 \mathrm{~min}$, at a cooling rate of $0.30^{\circ} \mathrm{C} / \mathrm{min}$. The semen was then transferred to a refrigerator for a further $30 \mathrm{~min}$, where it reached $4^{\circ} \mathrm{C}$ at $0.37^{\circ} \mathrm{C} / \mathrm{min}$. At the end of this time, a second portion of the extender containing glycerol was added to the sample and sperm was packed into $0.25 \mathrm{ml}$ plastic straws. Finally, all straws were horizontally placed in a thermal box for $5 \mathrm{~min}, 5 \mathrm{~cm}$ above the liquid nitrogen $\left(\mathrm{N}_{2}\right)$ level, reaching a temperature close to $-70^{\circ} \mathrm{C}$ in vapor and then plunged into liquid $\mathrm{N}_{2}$. After one week, the semen was thawed in a water bath at $38^{\circ} \mathrm{C} / 1 \mathrm{~min}$ and kept there for $30 \mathrm{~min}$ for a thermoresistance test (Silva et al., 2003).
Sperm motility and vigor were appraised after collection, first dilution, cooling, glycerol addition, immediately after thawing and at 15 and 30min post-thawing on a glass slide over a warmed plate coupled to a light microscope. Sperm morphology was analyzed after semen collection and thawing.

The results were expressed as mean and standard deviation and were analyzed by the Statview 5.0 software (Statview..., 1998). Percentage data concerning to sperm motility and morphology were subjected to arcsine transformation. Differences among the seminal parameters of dogs were analyzed by the Kruskal-Wallis test. The effects of the dilution rates on sperm motility and morphology, as well as the effects of the incubation period on motility were evaluated by the Student $t$-test. The effects of dilution rates and incubation period on vigor were analyzed by the Mann-Whitney-test. The results were considered significant when $\mathrm{P}<0.05$.

\section{RESULTS AND DISCUSSION}

Fresh dog semen was white in color with milky viscosity. Values for sperm motility, vigor, concentration and morphology, as well as second fraction volume are shown in Table 1. Statistical analysis showed that dogs were a homogeneous population, since no differences were detected among them $(\mathrm{P}>0.05)$. Furthermore, seminal parameters were in the normal range for canine species (Oettlé, 1993; Johnston et al., 2001).

Fig. 1 and 2 show similar patterns of sperm motility and vigor for both dilution rates throughout extension, cooling, glycerol addition and thawing. After thawing, a reduction in motility and vigor was observed in both treatments, which showed no difference from each other $(\mathrm{P}>0.05)$. It is possible that the reduction of seminal quality after thawing was due to a sum of factors, such as the crystallization phase that occurs between -6 and $-10^{\circ} \mathrm{C}$, whose effect is reduced by the addition of the cryoprotector (Colas, 1975); the toxic action of glycerol, which can cause physical-chemical alterations that lead to the rupture of the sperm membrane or the removal of important membrane proteins in spite of having protective effects on the sperm cell; the osmotic alterations originating from the addition of the cryoprotector and the ionic rearrangement that occurs during 
freezing; the alterations in the lipid-protein bilayer and modifications in the membrane enzymes of the sperm cell (Holt, 2000); and the thermal shock due to the several temperature changes to which sperm are subjected (Farstad, 1996). Many researchers have used sperm motility as the main parameter for the evaluation of freezing/thawing techniques applied to canine semen (Ivanova-Kicheva et al., 1997; Bueno et al., 2001). In this study, the percentage of mobile spermatozoa obtained after thawing using both dilution rates $(60 \%)$ was within the ideal range for the performance of artificial insemination using frozen semen (Concannon and Battista, 1989).

Table 1. Means and standard deviation of the characteristics of two ejaculates obtained from donor stud dogs

\begin{tabular}{lccccc}
\hline Dog & $\begin{array}{c}\text { Sperm motility } \\
(\%)\end{array}$ & $\begin{array}{c}\text { Sperm vigor } \\
(0-5)\end{array}$ & $\begin{array}{c}\text { Concentration } \\
\left(\mathrm{x} 10^{6} \text { spermatozoa/ml }\right)\end{array}$ & $\begin{array}{c}\text { Normal sperm } \\
(\%)\end{array}$ & $\begin{array}{c}2^{\text {nd }} \text { fraction volume } \\
(\mathrm{ml})\end{array}$ \\
\hline 1 & $95.0 \pm 0.0$ & $5.0 \pm 0.0$ & $1250.0 \pm 70.7$ & $77.5 \pm 8.5$ & $0.9 \pm 0.1$ \\
2 & $97.5 \pm 3.5$ & $5.0 \pm 0.0$ & $520.0 \pm 113.1$ & $76.0 \pm 0.0$ & $0.5 \pm 0.1$ \\
3 & $92.5 \pm 3.5$ & $5.0 \pm 0.0$ & $885.0 \pm 502.1$ & $78.3 \pm 6.7$ & $1.6 \pm 0.8$ \\
4 & $95.0 \pm 0.0$ & $5.0 \pm 0.0$ & $1370.0 \pm 650.5$ & $80.3 \pm 3.2$ & $2.4 \pm 2.1$ \\
5 & $99.0 \pm 1.4$ & $5.0 \pm 0.0$ & $2760.0 \pm 28.3$ & $79.8 \pm 1.1$ & $1.9 \pm 0.1$ \\
6 & $100.0 \pm 0.0$ & $5.0 \pm 0.0$ & $1740.0 \pm 367.7$ & $81.3 \pm 5.3$ & $1.1 \pm 0.2$ \\
Total & $96.5 \pm 0.9$ & $5.0 \pm 0.0$ & $1420.8 \pm 228.3$ & $79.2 \pm 1.4$ & $1.4 \pm 0.3$ \\
\hline
\end{tabular}

No statistical differences were observed among dogs ( $\mathrm{P}>0.05$; Kruskal-Wallis test).

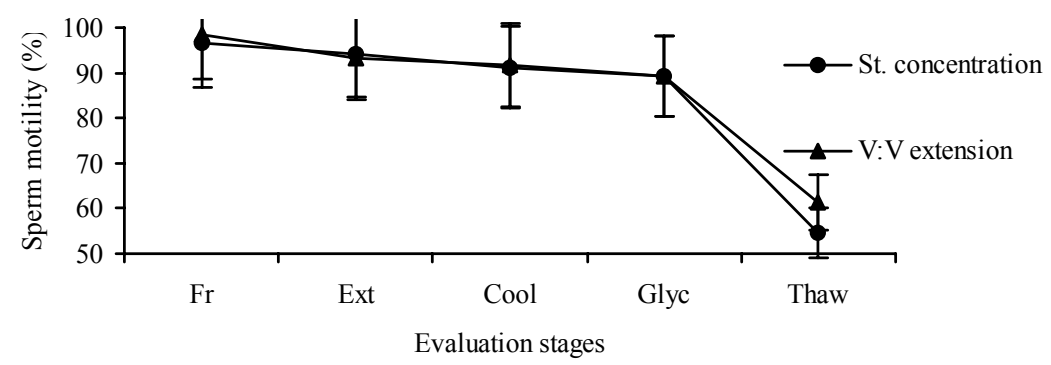

Figure 1. Sperm motility of fresh (Fr), extended (Ext), cooled (Cool), glycerol-supplemented (Glyc) and frozen/thawed (Thaw) semen, submitted to standardized sperm concentration (St. concentration) or volume:volume extension ( $\mathrm{V}: \mathrm{V}$ extension - $\mathrm{P}>0.05$; Student's $\mathrm{t}$ test).

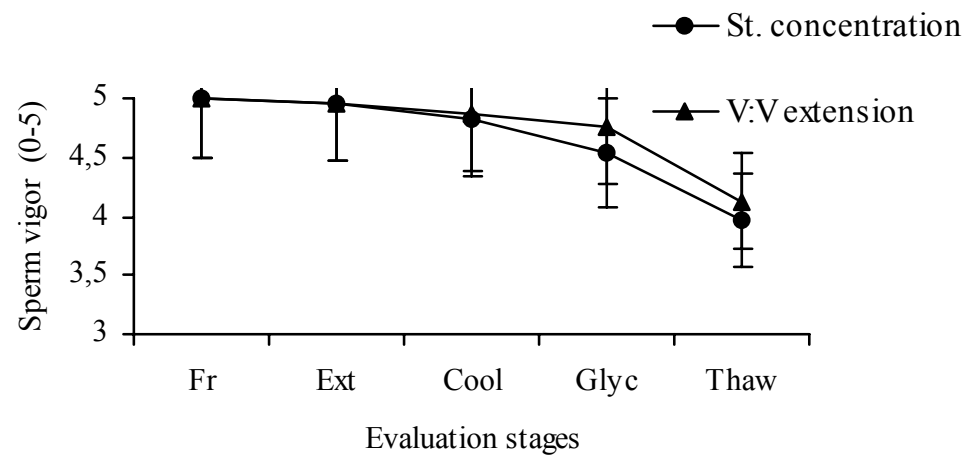

Figure 2. Sperm vigor of fresh (Fr), extended (Ext), cooled (Cool), glycerol-supplemented (Glyc) and frozen/thawed (thaw) semen, submitted to standardized sperm concentration (St. concentration) or volume:volume extension ( $\mathrm{V}: \mathrm{V}$ extension - $\mathrm{P}>0.05$; Mann-Whitney test). 
The effects of semen incubation at $38^{\circ} \mathrm{C}$ for $30 \mathrm{~min}$ are shown in Tables 2 and 3. During the thermoresistance test, sperm motility declined significantly $15 \mathrm{~min}$ after thawing in both treatments, but vigor only declined at $30 \mathrm{~min}$ $(\mathrm{P}<0.05)$. However, at $15 \mathrm{~min}$, both parameters were still within the acceptable range $(30-50 \%)$ for the use of frozen semen for insemination (Concannon and Battista, 1989). Furthermore, $15 \mathrm{~min}$ is more than enough time for the semen to reach the fertilization site, since Tsutsui et al. (1989) showed that canine spermatozoa can reach the uterine horn $2 \mathrm{~min}$ after vaginal deposition. On the other hand, post-thawing dilution could improve sperm longevity, as shown by other authors (Ström et al., 1997; Peña and Linde-Forsberg, 2000).

Table 2. Sperm motility of thawed canine semen submitted to standardized sperm concentration or volume:volume extension and maintained at $38^{\circ} \mathrm{C}$ for 30 minutes

\begin{tabular}{lcc}
\hline \multirow{2}{*}{$\begin{array}{l}\text { Evaluations post } \\
\text { thawing (min) }\end{array}$} & \multicolumn{2}{c}{ Sperm motility (\%) } \\
\cline { 2 - 3 } & $\begin{array}{l}\text { Standardized } \\
\text { concentration }\end{array}$ & $\mathrm{V}: \mathrm{V}$ extension \\
\hline 0 & $54.6 \pm 11.2 \mathrm{a}$ & $61.3 \pm 9.1 \mathrm{a}$ \\
15 & $41.3 \pm 10.9 \mathrm{~b}$ & $44.6 \pm 13.1 \mathrm{~b}$ \\
30 & $26.3 \pm 16.5 \mathrm{c}$ & $31.3 \pm 15.4 \mathrm{c}$ \\
\hline
\end{tabular}

Values followed by different lower case letters differ between rows $(\mathrm{P}<0.05$; Student's $\mathrm{t}$ test $)$; no differences between columns were observed ( $\mathrm{P}>0.05$; Student's t test).

Table 3. Sperm vigor of thawed canine semen submitted to standardized sperm concentration or volume:volume extension and maintained at $38^{\circ} \mathrm{C}$ for 30 minutes

\begin{tabular}{lcc}
\hline \multirow{2}{*}{$\begin{array}{l}\text { Evaluations post } \\
\text { thawing (min) }\end{array}$} & \multicolumn{2}{c}{ Sperm vigor $(0-5)$} \\
\cline { 2 - 3 } & $\begin{array}{l}\text { Standardized } \\
\text { concentration }\end{array}$ & $\mathrm{V}: \mathrm{V}$ extension \\
\hline 0 & $4.0 \pm 0.3 \mathrm{a}$ & $4.1 \pm 0.2 \mathrm{a}$ \\
15 & $3.8 \pm 0.4 \mathrm{a}$ & $3.8 \pm 0.7 \mathrm{a}$ \\
30 & $2.6 \pm 1.2 \mathrm{~b}$ & $3.0 \pm 1.1 \mathrm{~b}$ \\
\hline Values followed by different lower case letters differ between \\
rows $(\mathrm{P}<0.05 ;$ Man-Whitney test); no differences between \\
columns were observed (P>0.05; Man-Whitney test).
\end{tabular}

In human species (Alvarez et al., 1996), the thermoresistance test has been shown to be a safe clinical test to predict the fertilizing potential of semen. However, in the dog, Ström et al. (1997) stated that low sperm longevity is not necessarily associated with low fertility. These authors found a high sperm motility after thawing $(74 \%)$, but semen showed low longevity $(20 \%$ after $1 \mathrm{~h}$ at $37^{\circ} \mathrm{C}$ ). However, a fertility rate of $85 \%$ was obtained in intra-uterine artificial insemination. Thus, the existence of a correlation between post-thawing sperm longevity and in vivo fertility rate needs to be confirmed.

Even if the dogs used in this experiment initially constituted a homogeneous population (Table 1), wide individual variability was observed in response to the freezing procedure and in the thermoresistance test, with $30-70 \%$ variation in sperm motility immediately after thawing, and a $0-50 \%$ variation at $30 \mathrm{~min}$. According to $\mathrm{Yu}$ et al. (2002), one aspect of sperm cryobiology that is different from other types of cells is the fact that spermatozoa from different individuals may exhibit significantly different responses to the same freezing treatment, which has also been observed among dogs (Silva et al., 2003).

Oettlé (1993) described the relationship between the percentage of morphologically normal spermatozoa and fertility in dogs. This author verified that samples with less than $60 \%$ morphologically normal sperm population rate would cause a significant reduction in fertility. Concerning this parameter, in the present study no differences were observed between fresh and thawed semen for either treatment $(\mathrm{P}>0.05)$ regarding normal sperm morphology rate, which was higher than $70 \%$ (Table 4 ). This shows that the freezing protocols were efficient in preserving sperm morphology, regardless of the dilution rate. Detached sperm heads were the most frequent abnormality found both in fresh and in frozen semen. However, by analyzing separately each sperm abnormality, a higher incidence of kinked and coiled tails was verified in both treatments compared to fresh semen $(\mathrm{P}<0.05)$. This finding was probably due to the cold shock effect or to glycerol exposure, as reported for red wolves (Goodrowe et al., 1998). Moreover, a freezing procedure using volume:volume extension showed a low incidence of proximal droplets $(\mathrm{P}<0.05)$. Possibly, freezing/thawing procedures damaged the droplet membrane releasing its enzymes, which could have adverse effects on semen viability. Even if no acrosome abnormality was seen in fresh semen, no differences were found between fresh and frozen semen $(\mathrm{P}>0.05)$. The staining method used in this experiment was not efficient in showing internal acrosome details, 
and only acrosome detachment was verified in frozen semen. Finally, a higher rate of bent midpieces was verified in fresh than in frozen semen using a standardized concentration $(\mathrm{P}<0.05)$. This is an uncommon fact that is difficult to explain since this abnormality was not verified in three ejaculates after freezing, which randomly reduces the normal distribution of bent midpieces.

Table 4. Sperm morphology observed in canine fresh and frozen-thawed semen submitted to standardized sperm concentration or volume:volume extension

\begin{tabular}{lccc} 
& \multicolumn{3}{c}{ Sperm morphology (\%) } \\
\cline { 2 - 4 } & Fresh & $\begin{array}{c}\text { Standardized } \\
\text { concentration }\end{array}$ & V:V extension \\
\hline Normal sperm & $79.2 \pm 1.4$ & $76.5 \pm 4.8$ & $74.3 \pm 6.9$ \\
Head abnormalities & & & \\
Detached head & $11.6 \pm 3.2$ & $10.8 \pm 2.2$ & $12.2 \pm 3.3$ \\
Double head & $0.4 \pm 0.2$ & $0.0 \pm 0.0$ & $0.4 \pm 0.2$ \\
Macrocephalic & $0.1 \pm 0.2$ & $0.3 \pm 0.6$ & $0.1 \pm 0.2$ \\
Microcephalic & $0.1 \pm 0.3$ & $0.1 \pm 0.2$ & $0.0 \pm 0.0$ \\
Pyriform head & $0.3 \pm 0.4$ & $0.2 \pm 0.5$ & $0.2 \pm 0.4$ \\
Detached acrosome & $0.0 \pm 0.0$ & $0.3 \pm 0.5$ & $0.1 \pm 0.2$ \\
Midpiece abnormalities & & & \\
Thickened midpiece & $0.0 \pm 0.0$ & $0.0 \pm 0.0$ & $0.1 \pm 0.2$ \\
Bent midpiece & $2.3 \pm 1.7 \mathrm{~A}$ & $0.9 \pm 0.9 \mathrm{~B}$ & $0.0 \pm 0.0 \mathrm{~B}$ \\
Proximal droplet & $0.2 \pm 0.3 \mathrm{~A}$ & $0.1 \pm 0.2 \mathrm{AB}$ & $0.0 \pm 0.0$ \\
Distal droplet & $0.1 \pm 0.2$ & $0.0 \pm 0.0$ & $0.1 \pm 0.2 \mathrm{~B}$ \\
Abaxial insertion & $0.3 \pm 0.4 \mathrm{~A}$ & $0.0 \pm 0.0 \mathrm{~B}$ & $4.3 \pm 2.4 \mathrm{~B}$ \\
Tail abnormalities & & & $6.8 \pm 2.9 \mathrm{~B}$ \\
Kinked tail & $1.7 \pm 1.1 \mathrm{~A}$ & $4.3 \pm 1.7 \mathrm{~B}$ & $0.6 \pm 1.0$ \\
Coiled tail & $4.0 \pm 1.5 \mathrm{~A}$ & $6.0 \pm 2.9 \mathrm{~B}$ & $0.1 \pm 0.1$ \\
Strongly coiled tail & $0.5 \pm 1.1$ & $0.6 \pm 1.2$ & $0.1 \pm 0.2$ \\
Double & $0.0 \pm 0.0$ &
\end{tabular}

Values followed by different capital letters differ among columns $(\mathrm{P}<0.05$; Student's $\mathrm{t}$ test $)$.

According the dilution rates, no differences were observed in the seminal characteristics, except for some morphological abnormalities. In addition, while the standard sperm concentration was always $200 \times 10^{6}$ spermatozoa $/ \mathrm{ml}$, the final sperm concentration in volume:volume extension ranged from 220 to $1390 \times 10^{6}$ spermatozoa $/ \mathrm{ml}$, with an average of $684.1 \pm 403.6 \times 10^{6}$ spermatozoa $/ \mathrm{ml}$. In general, special attention should be given to dilution rate, which seems to be an important factor influencing semen viability after the freezing/thawing process. Mann (1964) suggested that excessive dilution leads to permanent loss of motility, metabolic activity and fertilizing capacity in vivo. The mechanism of sperm inactivation by excessive dilution resembled senescence of spermatozoa during storage as a result of cold shock, because there is evidence that such treatments do indeed result in the destabilization of sperm membranes and impairment of their function. Furthermore, recent reports have shown that seminal plasma proteins are important for the maintenance of semen viability in rams, preventing cold-shock damage to the spermatozoal membrane (Barrios et al., 2000; Pérez-Pé et al., 2001). In dogs, an excessive dilution could minimize the beneficial effects of proteins from testicular and epidydimal fluids present in sperm fraction. In fact, very high dilution rates, such as one part of semen to 16 or 32 parts extender, cause a significant decrease in sperm progressive motility (Wales and White, 1963; England, 1993). Otherwise, for stallion semen, Varner et al (1987) reported that dilution rates based in a lower standardized concentration of $25 \times 10^{6}$ spermatozoa $/ \mathrm{ml}$ improved the longevity of spermatozoa motility and showed better results than dilutions in greater sperm concentrations such as 50 and $100 \times 10^{6}$ spermatozoa $/ \mathrm{ml}$. Thus, further studies must to be conducted in order to determine the efficiency of other dilution rates using other 
extenders and freezing/thawing procedures for canine semen.

In conclusion, a sperm concentration standardized at $200 \times 10^{6}$ spermatozoa $/ \mathrm{ml}$ and volume:volume extension at one part semen to one part extender are efficient dilution rates for canine semen freezing.

\section{ACKNOLEDGEMENTS}

The authors thank DVM Daniel C. Uchoa (Grande Canafístula Kennel) for providing the animals used in the experiment.

\section{REFERENCES}

ALVAREZ, J.G.; MINARETZIS, D.; BRENTBARRET, C. et al. The sperm stress test: a novel test that predicts pregnancy in assisted reproductive techniques. Fertil. Steril., v.65, p.400-405, 1996.

BARRIOS, B.; PÉREZ-PÉ, R.; GALLEGO, M. et al. Seminal plasma proteins revert the coldshock damage on ram sperm membrane. Biol. Reprod., v.63, p.1531-1537, 2000.

BUENO, R.; COSTA, E.P.; GUIMARÃES, J.D. et al. Qualidade espermática do sêmen criopreservado de cães - Efeito do meio diluidor. Arq. Bras. Med. Vet. Zootec., v.53, p.364-371, 2001.

CARDOSO, R.C.S.; SILVA, A.R.; UCHOA, D.C. et al. Cryopreservation of canine semen using a coconut water extender with egg yolk and three different glycerol concentrations. Theriogenology, v.59, p.743-751, 2003.

COLAS, G. Effect of initial freezing temperature, addition of glycerol and dilution on the survival and fertilizing ability of deep frozen ram semen. J. Reprod. Fertil., v.42, p.277-285, 1975.

CONCANNON, P.W.; BATTISTA, M. Canine semen freezing and artificial insemination. In: KIRK R.W. (Ed.). Current veterinary therapy. Philadelphia: WB Saunders, 1989. p.1247-1259.

ENGLAND, G.C.W. Cryopreservation of dog semen: a review. J. Reprod. Fertil., v.47, p.243 $255,1993$.
ENGLAND, G.C.W.; PONZIO, P. Comparison of the quality of frozen thawed and cooledrewarmed dog semen. Theriogenology, v.46, p.165-171, 1996.

FARSTAD, W. Semen cryopreservation in dogs and foxes. Anim. Reprod. Sci., v.42, p.251-260, 1996.

GOODROWE, K.L.; HAY, M.A.; PLATZ, C.C. et al. Characteristics of fresh and frozen-thawed red wolf (Canis rufus) spermatozoa. Anim. Reprod. Sci., v.53, p.299-308, 1998.

HOLT, W.V. Fundamental aspects of sperm cryobiology: the importance of species and individual differences. Theriogenology, v.53, p.47-58, 2000.

IGUER-OUADA, M. Medically assisted procreation in canine species: analyses and $4{ }^{\circ} \mathrm{C}$ preservation of semen. 2001. 219f. Tese (Doutorado) - Université de Liège, Liège.

IVANOVA-KICHEVA, M.G.; BOBADOV, N.D.; SOMLEV, B. Cryopreservation of canine semen in pellets and in 5-mL aluminum tubes using three extenders. Theriogenology, v.48, p.1343-1349, 1997.

JOHNSTON， S.D.; KUSTRITZ， M.V.R.; OLSON, P.N.S. Canine and feline theriogenology. Philadelphia: W.B.Saunders, 2001. 592p.

MANN, T. The biochemistry of semen and of the male reproductive tract. London: Methuen, 1964. 493p.

OETTLÉ, E.E. Sperm morphology and fertility in the dog. J. Reprod. Fertil., v.47, p.257-260, 1993.

PEÑA, A.; LINDE-FORSBERG, C. Effects of spermatozoa concentration and post-thaw dilution rate on survival after thawing of dog spermatozoa. Theriogenology, v.54, p.703-718, 2000.

PÉREZ-PÉ， R.; CÉBRIAN-PÉREZ， J.A.; MUIÑO-BLANCO, T. Semen plasma proteins prevent cold-shock membrane damage to ram spermatozoa. Theriogenology, v.56, p.425-434, 2001.

SILVA, A.R.; CARDOSO, R.C.S.; UCHOA, D.C. et al. Effect of Tris-buffer, egg yolk and glycerol on canine semen freezing. Vet. J., v.164, p.244-246, 2002. 
SILVA, A.R.; CARDOSO, R.C.S.; UCHOA, D.C. et al. Quality of canine semen submitted to single or fractionated glycerol addition during the freezing process. Theriogenology, v.59, p.821-829, 2003.

SILVA, A.R.; MORATO, R.G.; SILVA, L.D.M. The potential of gamete recovery from nondomestic canids and felids. Anim. Reprod. Sci., v.81, p.159-175, 2004.

SILVA, L.D.M.; VERSTEGEN, J. Comparisons between three different extenders for canine intrauterine insemination with frozen thawed spermatozoa. Theriogenology, v.44, p.571-579, 1995.

SIRIVAIDYAPONG, S.; URSEN, P.; BEVERS, M.M. et al. Effect of prostatic fluid on motility, viability and acrosome integrity of chilled and frozen-thawed dog spermatozoa. J. Reprod. Fertil., v.57, p.383-386, 2001.

SOARES, M.P.; ROSSI, C.A.R.; MEZZALIRA, A. et al. Etileno glicol na criopreservação de sêmen canino. Ciên. Rural, v.32, p.649-655, 2002.

STATVIEW. Version 5.0. statview reference. Cary: SAS Institute, 1998. 528p.

STRÖM, B.; ROTA, A.; LINDE-FORSBERG, C. In vitro characteristics of canine spermatozoa subjected to two methods of cryopreservation. Theriogenology, v.48, p.247-256, 1997.

TSUTSUI, T.; HASE, M.; HORI, T. et al. Effect of adition of Orvus ES paste to frozen canine semen extender on sperm acrosomes. J. Vet. Med. Sci., v.62, p.537-538, 2000.

TSUTSUI, T.; KAWAKAMI, E.; MURAO, I. et al. Transport of spermatozoa in the reproductive tract of the bitch: observations through uterine fistula. Jpn. J. Vet. Sci., v.51, p.560-565, 1989.

VARNER, D.D.; BLANCHARD, T.L.; LOVE, C.L. et al. Effects of semen fractionation and dilution ratio on equine spermatozoal motility parameters. Theriogenology, v.28, p.709-723, 1987.

WALES, R.G.; WHITE, I.G. Viability of diluted dog spermatozoa in vitro. J. Reprod. Fertil., v.5, p.67-76, 1963.

YILDIZ, C.; KAYA, A.; AKSOY, M. et al. Influence of sugar supplementation of the extender on motility, viability and acrosomal integrity of dog spermatozoa during freezing. Theriogenology, v.54, p.579-585, 2000.

YU, I.; SONGSANSSEN, N.; GODKE, R.A. et al Differences among dogs in response of their spermatozoa to cryopreservation using various cooling and warming rates. Cryobiology, v.44, p.62-78, 2002. 